\title{
Serum free embryo culture medium improves in vitro survival of bovine blastocysts to vitrification
}

\author{
E. Gómez, A. Rodríguez, M. Muñoz, J.N. Caamaño, \\ C.O. Hidalgo, E. Morán, N. Facal, C. Díez * \\ SERIDA, Camino de los Claveles 604, Somió. 33205 Gijón, Spain
}

Received 24 September 2007; received in revised form 14 December 2007; accepted 24 December 2007

\begin{abstract}
The aim of this study was to examine the effects of co-culture with Vero cells during the in vitro maturation (IVM) and three culture media, B2 $+5 \%$ fetal calf serum (FCS) on Vero cells, synthetic oviduct fluid (SOF) $+5 \%$ FCS, and SOF $+20 \mathrm{~g} \mathrm{~L}^{-1}$ bovine serum albumin (BSA), on the developmental competence of the embryos and their ability to survive vitrification/warming. We also tested the effect of morphological quality and the age of the embryo on its sensitivity to vitrification. The IVM system neither affects the embryo development up to Day 7 nor survival rates after vitrification. The culture of embryos in SOF + FCS and in Vero cells + B2 allowed obtaining more Day 6 and Day 7 blastocysts, and a higher \% of Day 7 blastocysts vitrified than culture in SOF + BSA. Contrarily, on Day 8, more blastocysts were vitrified in SOF + BSA than in SOF + FCS. Blastocysts quality affected development after vitrification/warming, and Day 7 embryos showed higher survival rates than their Day 8 counterparts. Day 7 blastocysts produced in Vero cells or in SOF + BSA survived at higher rates than those produced in SOF + FCS at 24 and $48 \mathrm{~h}$ after warming. Embryo culture with BSA allows obtaining hatching rates after vitrification/warming higher than those obtained after coculture with Vero cells in B2 and FCS. Moreover, this system provides hatching rates from Day 8 blastocysts comparable to those obtained on Day 7 in Vero cells. Further studies, including embryo transfer to recipients, are needed to clarify factors affecting the freezability of in vitro produced bovine embryos.
\end{abstract}

(C) 2008 Elsevier Inc. All rights reserved.

Keywords: In vitro bovine embryo; Vitrification; BSA; Co-culture

\section{Introduction}

In vitro culture of bovine embryos derived from in vitro maturation and fertilization (IVM-IVF) have succeeded in producing calves [1,2]. An adequate in vitro culture system for bovine zygotes is required for large-scale embryo production by IVM-IVF and genetic

\footnotetext{
* Corresponding author. Tel.: +34 985195300x04; fax: +34 985195310 .

E-mail addresses: mcdiez@serida.org, cdm33205@yahoo.es (C. Díez).
}

improvement by means of ovum pick-up (OPU) and IVM-IVF.

Until now, the major obstacle associated with the extensive use of this technology is the lack of suitable methods to preserve in vitro produced embryos. Culture of embryos in vitro results in embryos fundamentally different from those produced in vivo, particularly for ruminants $[3,4]$. In general, the longer in vitro culture, the more deviation occurs relative to embryos recovered in vivo; this phenomenon appears to be exacerbated when in vitro oocyte maturation and in vitro fertilization procedures precede embryo culture [5,6]. Darker cytoplasm, lower density, swollen blastomeres, slower 
growth rate, and high thermal sensitivity $[7,8]$ make in vitro produced embryos more sensitive to cryopreservation, yielding lower pregnancy rates [9] than in vivo recovered embryos.

The freezing sensitivity should be considered as a factor affecting the quality of the in vitro produced bovine blastocysts [10-13]. Improvement of embryo survival after freezing can be achieved by changing the conditions of in vitro culture, and/or modifying "standard" cryopreservation procedures [14].

Bovine IVM-IVF zygotes were first cultured with cumulus cells $[2,15]$, oviduct epithelial cells $[1,16]$, amnion cells [17], buffalo rat cell liver cells [18], in TCM199 supplemented bovine serum. Also Vero cells have been employed together with B2 medium supplemented with fetal calf serum (FCS) for producing in vitro bovine embryos [19]. Simplification of in vitro culture conditions offers the advantage of reducing the number of problems due to changes in the composition of biological fluids and co-culture with somatic cells, and consequently, other media for producing bovine embryos in vitro have been developed.

Almost all media used for embryo development contain serum or bovine serum albumin (BSA) as a source of protein; several authors have demonstrated favourable effects of these products on embryo development [20]. Although the role of serum is not completely known (for review, see [21]) it has been demonstrated that serum has a biphasic effect inhibiting early cleavage divisions and accelerating the development of morula and blastocysts [22-24]. It is also expected that serum provides energy substrates, amino-acids, vitamins, growth factors and heavy-metal chelators at concentrations that vary among batches [25]. A higher development rate to the blastocyst stage is obtained from media supported with serum, but the serum effectiveness for the vitro embryo production might change considerably from one batch to another [23]. Furthermore, embryos produced with serum show alterations in their ultrastructure, impaired compaction, abnormal blastulation, aberrant mRNA expression profiles and large calf syndrome with greater incidences of stillbirths and deaths after birth [26-28]. Moreover, bovine-derived sera or proteins have recently been avoided especially in human in vitro production systems because of the appearance of bovine spongiform encephalopathy and a viral or prion contamination risk. Because of these reasons, there has been a trend to use more defined proteins, such as BSA, human serum albumin and synthetic serum preparations instead of undefined natural serum preparations.

At present, slow freezing and vitrification are commonly used to cryopreserve in vitro produced bovine embryos. Slow freezing of in vitro produced embryos reduced post thaw survival rates compared with their in vivo counterparts, mostly due to their susceptibility to ice crystal formation. Cryopreservation of embryos by vitrification yields higher survival than conventional slow freezing [14,29-31].

The optimum system for the production of bovine embryos and improving the freezability of blastocysts obtained still remains to be clarified. Consequently, the aim of the present study was to examine the effects of co-culture with Vero cells during the IVM of bovine oocytes in combination with the use of three culture media, on the developmental competence of the embryos and its ability to survive to vitrification and warming. We also tested the influence of morphological quality and the age of the embryo on vitrification survival.

\section{Materials and methods}

Except otherwise indicated, all reagents were purchased from Sigma. Culture media were prepared with Milli-Q water, grade I.

\subsection{Oocyte recovery}

Ovaries recovered from slaughtered cows were placed in $\mathrm{NaCl}$ solution $\left(9 \mathrm{mg} \mathrm{mL}^{-1}\right)$ containing antibiotics (penicillin, $100 \mathrm{UI} \mathrm{mL}^{-1}$ and streptomycin sulphate, $100 \mu \mathrm{g} \mathrm{mL}^{-1}$ ) and maintained at $30-35{ }^{\circ} \mathrm{C}$ until recovery of cumulus-oocyte complexes (COCs). Ovaries were washed twice in distilled water and once in freshly prepared saline. The COCs were aspirated from 2 to $7 \mathrm{~mm}$ visible follicles through an 18-gauge needle connected to a syringe, and recovered in a $50 \mathrm{~mL}$ Corning tube. Follicular fluid and COCs were placed in an ovum concentrator (Em-Con, Comextrade, Spain) and rinsed 3 times with holding medium (HM: TCM199 [Gibco, Barcelona, Spain] + $25 \mathrm{mM}$ HEPES + BSA $0.4 \mathrm{~g} \mathrm{~L}^{-1}$ ) supplemented with $2 \mathrm{UI} \mathrm{mL}^{-1}$ of heparin.

\subsection{In vitro maturation}

Only oocytes enclosed in a compact cumulus with evenly granulated cytoplasm were selected for IVM. The COCs were washed 3 times in HM and twice in maturation medium, which consisted of TCM199, $\mathrm{HNaCO}_{3}\left(2.2 \mathrm{~g} \mathrm{~L}^{-1}\right)$, FCS (10\% v:v) (Sigma, Madrid, Spain; lot 88H8415), FSHp $\left(1 \mu \mathrm{g} \mathrm{mL}^{-1}\right), \quad \mathrm{LH}$ $\left(5 \mu \mathrm{g} \mathrm{mL}^{-1}\right)$ and $17 \beta$-estradiol $\left(1 \mu \mathrm{g} \mathrm{mL}^{-1}\right)$. Half of the COCs were selected for maturation in co-culture with Vero cells [32], while the remainder COCs were 
matured in the same medium without cells. Maturation was performed by culturing approximately $50 \mathrm{COCs}$ in $500 \mu \mathrm{L}$ of maturation medium in four-well dishes at $39{ }^{\circ} \mathrm{C}$ in $5 \% \mathrm{CO}_{2}$ in air and high humidity.

Vero cells for maturation were seeded $48 \mathrm{~h}$ before its use in four-well dishes with $500 \mu \mathrm{L}$ of TCM199, $\mathrm{HNaCO} 3\left(2.2 \mathrm{~g} \mathrm{~L}^{-1}\right)$ and fetal calf serum (FCS, $10 \%$ $\mathrm{v}: \mathrm{v})$. One hour before putting the COCs in maturation, this medium was replaced by the IVM medium.

\subsection{In vitro fertilization}

Sperm separation was carried out using a swim-up procedure similar to that reported by Parrish et al. [33]. Briefly, semen from one frozen straw of a single bull was thawed in a water bath and added to a polystyrene tube containing $1 \mathrm{~mL}$ of pre-equilibrated Sperm-TALP. After $1 \mathrm{~h}$ of incubation, approximately $700 \mu \mathrm{L}$ of the upper layer of supernatant containing the motile sperm was removed. The spermatozoa were centrifuged for 7 min at $200 \times g$ and the supernatant aspirated to leave a pellet of approximately $100 \mu \mathrm{L}$ in volume. Sperm concentration was determined with a haemocytometer. After 22-24 h of maturation, COCs were washed 2 times in holding medium and placed in four-well culture dishes containing pre-equilibrated fertilization medium (Fert-TALP) with heparin $\left(10 \mu \mathrm{g} \mathrm{mL}^{-1}\right.$, Calbiochem, La Jolla, CA). Spermatozoa were then added at a concentration of $2 \times 10^{6}$ cells mL $\mathrm{m}^{-1}$ in $500 \mu \mathrm{L}$ of medium per well containing a maximum of 100 COCs. In vitro fertilization (IVF) was accomplished by incubating oocytes and sperm cells together for 18$20 \mathrm{~h}$ at $39{ }^{\circ} \mathrm{C}$ in $5 \% \mathrm{CO}_{2}$ and high humidity.

\subsection{In vitro culture}

Presumptive zygotes were vortexed for $2 \mathrm{~min}$ to separate cumulus cells, washed 3 times in HM and twice in the culture medium before putting them in the culture droplets. The zygotes were randomly assigned to one of three culture systems:

(1) Vero Group: zygotes were placed in drops of $50 \mu \mathrm{L}$ $\mathrm{B}_{2}$ medium (CCB, Paris, France) supplemented with $5 \%$ FCS, seeded with Vero cells and overlaid with mineral oil. Droplets of $50 \mu \mathrm{L}$ were prepared in four-well dishes under mineral oil and equilibrated for $2 \mathrm{~h}$ before addition of a maximum of 25 zygotes/ microdrop. Co-cultures were performed at $39{ }^{\circ} \mathrm{C}$ under $5 \% \mathrm{CO}_{2}$ in air. Vero cells were seeded $48 \mathrm{~h}$ before its use in $50 \mu \mathrm{L}$ microdrops of $\mathrm{B} 2+10 \%$ FCS (v:v). One hour before putting the zygotes in culture, this medium was replaced by fresh $\mathrm{B} 2+5 \%$ FCS. A half $(25 \mu \mathrm{L})$ of the culture droplet was daily renewed with fresh equilibrated B2 with 5\% FCS.

(2) SOF-FCS Group: embryo culture was performed in modified synthetic oviduct fluid (mSOF) with amino-acids, citrate and myo-inositol [30]. The FCS $(5 \%)$ was added at $42 \mathrm{~h}$ post-fertilization (postFIV).

(3) SOF-BSA Group: embryo culture was performed in $\mathrm{mSOF}$ containing amino-acids, citrate and myoinositol [27], and $20 \mathrm{~g} \mathrm{~L}^{-1} \mathrm{BSA}$.

The $\mathrm{mSOF}$ was adjusted to $285 \mathrm{mOsm}$ and $\mathrm{pH} 7.2-$ 7.3 , and cultures were carried out at $39{ }^{\circ} \mathrm{C}, 5 \% \mathrm{CO}_{2}$, $5 \% \mathrm{O}_{2}$ and $90 \% \mathrm{~N}_{2}$. Droplets of $50 \mu \mathrm{L} \mathrm{mSOF}$ were prepared in four-well dishes under mineral oil and equilibrated for $2 \mathrm{~h}$ before the addition of 35-40 zygotes per drop. Media were renewed at $66 \mathrm{~h}$ (day 3) and $138 \mathrm{~h}$ (day 6) post-FIV by moving the embryos to new droplets.

Embryonic development was recorded on days 3, 6, 7 and 8 .

\subsection{Vitrification and warming}

Day 7 and 8 expanded blastocysts were classified according to their morphological aspect as very good to excellent (Quality A: embryos showing a complete expansion with zona thinning, with a very compact and sole inner cell mass (ICM) and a homogeneous trophectoderm (TE)) and fair/regular (Quality B: expanded embryos smaller in size, but showing zona thinning as well, with a less compact ICM, or a discontinuous TE, showing a reduced number of extruded blastomeres).

Blastocysts were vitrified/warmed following the OPS method described by Vajta et al. [30] with minor modifications. Briefly, embryos were handled in a basic vitrification medium (BV), consisting of TCM199HEPES + 20\% FCS. All procedures were performed in a warm room $\left(30^{\circ} \mathrm{C}\right)$ on a heated surface $\left(41^{\circ} \mathrm{C}\right)$. Groups of 4-5 blastocysts were exposed to BV with $10 \%$ EG + 10\% DMSO (vitrification solution-1; VS1) for $3 \mathrm{~min}$ and then moved into a well containing BV with $20 \% \mathrm{EG}+20 \% \mathrm{DMSO}+0.5 \mathrm{M}$ sucrose (vitrification solution-2; VS2). After a quick passage of embryos in VS2, a drop of $6 \mu \mathrm{L} \mathrm{VS} 2$ containing the oocytes was made. Blastocysts were loaded into OPS straws (sOPS; Comextrade, Spain) in an approximately $1 \mathrm{~mm}$ higher cylinder of VS2 containing the embryos, formed by capillary action by touching the narrow end of the straw with the droplet. Then, the straws were plunged in liquid 
nitrogen. The time spent by the embryos in VS2 (including loading) was 20-25 s.

Warming was conducted by immersing the pulled end of the straw directly in $1.2 \mathrm{~mL}$ of $0.25 \mathrm{M}$ sucrose in BV. They were kept for $5 \mathrm{~min}$, and then transferred into a $0.15 \mathrm{M}$ sucrose medium in $\mathrm{BV}$ for another $5 \mathrm{~min}$, and subsequently transferred and washed twice in $\mathrm{BV}$.

After warming, blastocysts were rinsed twice in the culture medium and then cultured in drops of $25 \mu \mathrm{L}$ of B2 medium supplemented with 5\% FCS, seeded with Vero cells and overlaid with mineral oil. Embryo survival was evaluated in terms of re-expansion and hatching rates at 24,48 and $72 \mathrm{~h}$.

\subsection{Experimental design}

Two IVM protocols (with and without co-culture with Vero cells, in the same IVM medium) were assayed in combination with three IVC media: (1) co-culture with Vero cells in $\mathrm{B} 2+5 \%$ of FCS; (2) SOF $+5 \%$ of FCS (added on Day 3) and (3) SOF $+20 \mathrm{~g} \mathrm{~L}^{-1}$ of BSA as substitute for serum. We analyzed embryo development and the percentage of blastocyst selected for vitrification.

In the second part of this study we examined the quality of the embryos produced in the above cited, three culture systems, to survive and hatch following vitrification and warming, and how the morphological appearance of the embryo and its age at vitrification (Day 7 and Day 8) affect survival.

\subsection{Statistical analysis}

Data were analyzed by the GLM procedure (SAS; 1999) [34], and Duncan's test for mean differences $(P<0.05)$. Values were expressed as $\mathrm{LSM} \pm$ S.E. Effects analyzed were presence/absence of Vero cells during IVM, culture system, blastocyst quality at cryopreservation (A and $\mathrm{B}$ ), and blastocyst age at cryopreservation (Day 7 and Day 8). A description of effects influencing the results is detailed in the section below.

\section{Results}

A total of 2057 COCs were submitted to the two IVM protocols and subsequently developed in the three embryo culture systems.

The presence of Vero cells during IVM did not affect the embryo development rates in any culture media used (data not shown). However, the presence of Vero cells during IVM and further culture in SOF + BSA significantly decreased the percentage of Day 8 blastocysts that were vitrified (IVM with cells $2.2 \pm 1.4$ vs. IVM without cells $6.2 \pm 1.2 ; P<0.05$ ).

Table 1 shows the cumulative effects of embryo culture treatments as corrected by the presence of Vero cells during the IVM. The culture of embryos in SOF + FCS and in Vero cells + B2 allowed obtaining more Day 6 and Day 7 blastocysts than culture in SOF + BSA. The highest $\%$ of Day 7 blastocysts vitrified was obtained from the culture in Vero cells and in SOF + FCS.

Table 1

Effects of culture in B2 on Vero cells (Vero), SOF + FCS (FCS) or SOF + $20 \mathrm{~g} \mathrm{~L}^{-1} \mathrm{BSA}$ (BSA) on embryo development and proportions of vitrified blastocysts

\begin{tabular}{|c|c|c|c|c|c|c|c|c|c|}
\hline \multirow[t]{2}{*}{ IVC group } & \multirow[t]{2}{*}{$R$} & \multirow[t]{2}{*}{$N$} & \multicolumn{2}{|l|}{ Day 3} & \multicolumn{2}{|l|}{ Day 6} & \multirow{2}{*}{$\frac{\text { Day } 7}{\% \mathrm{~B}}$} & \multirow{2}{*}{$\frac{\text { Day } 7}{\% \text { B vitrified }}$} & \multirow{2}{*}{$\frac{\text { Day } 8}{\% \text { B vitrified }}$} \\
\hline & & & $\%$ Cleaved & $\%$ 5-8 cells & $\% \mathrm{M}+\mathrm{B}$ & $\% \mathrm{~B}$ & & & \\
\hline Vero & 9 & 740 & $80.3 \pm 2.2$ & $62.4 \pm 3.3 \mathrm{a}$ & $42.8 \pm 3.2 \times$ & $9.5 \pm 2.0 \times$ & $23.6 \pm 2.7 \mathrm{a}$ & $6.7 \pm 1.8 \mathrm{a}$ & $4.4 \pm 1.0$ \\
\hline BSA & 7 & 569 & $80.2 \pm 1.8$ & $52.3 \pm 2.7 b$ & $30.2 \pm 2.6 \mathrm{y}$ & $2.0 \pm 1.6 \mathrm{y}$ & $2.7 \pm 2.2 b$ & $3.3 \pm 1.5 \mathrm{~b}$ & $3.8 \pm 0.8$ \\
\hline FCS & 7 & 721 & $80.7 \pm 2.0$ & $53.9 \pm 2.9 \mathrm{~b}$ & $33.3 \pm 2.8 \mathrm{y}$ & $14.4 \pm 1.8 \mathrm{z}$ & $21.2 \pm 2.4 \mathrm{a}$ & $7.2 \pm 1.6$ & $2.3 \pm 0.9$ \\
\hline
\end{tabular}

M: morulae; B: blastocysts; data are LSM \pm S.E. Embryo development rates and \% of vitrified embryos were a proportion of total COCs matured. Different letters within columns differ significantly ((x, y, z) $P<0.01$; (a, b) $P<0.05$ ).

Table 2

Effect of embryo quality (excellent, A or good, B) of Day 7 blastocysts on survival to vitrification and warming

\begin{tabular}{|c|c|c|c|c|c|}
\hline \multirow[t]{2}{*}{ Embryo quality } & \multirow[t]{2}{*}{$N$} & \multicolumn{2}{|l|}{$24 \mathrm{~h}$} & \multicolumn{2}{|l|}{$48 \mathrm{~h}$} \\
\hline & & Survival & Hatching & Survival & Hatching \\
\hline A & 151 & $51.9 \pm 0.04 \mathrm{a}$ & $10.7 \pm 0.02 \mathrm{a}$ & $57.2 \pm 0.04 \mathrm{a}$ & $29.9 \pm 0.03 \mathrm{a}$ \\
\hline B & 187 & $35.7 \pm 0.04 \mathrm{~b}$ & $5.2 \pm 0.02 \mathrm{~b}$ & $41.7 \pm 0.04 \mathrm{~b}$ & $9.6 \pm 0.03 b$ \\
\hline
\end{tabular}

Number of replicates: $14 ; N$ : number of blastocyst vitrified/warmed. Different letters within columns differ significantly $((\mathrm{a}, \mathrm{b}) P<0.01)$. 
Table 3

Survival and hatching rates after vitrification/warming of Day 7 and 8 blastocysts obtained after culture in B2 on Vero cells (Vero), SOF + FCS (FCS) or $\mathrm{SOF}+20 \mathrm{~g} \mathrm{~L}^{-1} \mathrm{BSA}(\mathrm{BSA})$

\begin{tabular}{|c|c|c|c|c|c|c|}
\hline \multirow[t]{2}{*}{ IVC group } & \multirow[t]{2}{*}{ Embryo age } & \multirow[t]{2}{*}{$N$} & \multicolumn{2}{|l|}{$24 \mathrm{~h}$} & \multicolumn{2}{|l|}{$48 \mathrm{~h}$} \\
\hline & & & Suvival & Hatching & Suvival & Hatching \\
\hline \multirow[t]{2}{*}{ Vero } & 7 & 104 & $62.1 \pm 0.05 \mathrm{ab}$ & $6.9 \pm 0.02 \mathrm{y}$ & $66.9 \pm 0.05 \mathrm{a}$ & $21.2 \pm 0.04 \mathrm{y}$ \\
\hline & 8 & 50 & $36.4 \pm 0.07 \mathrm{c}$ & $4.4 \pm 0.03 \mathrm{y}$ & $57.2 \pm 0.07 \mathrm{~b}$ & $11.7 \pm 0.05 \mathrm{y}$ \\
\hline \multirow[t]{2}{*}{ FCS } & 7 & 80 & $39.0 \pm 0.06 \mathrm{bc}$ & $7.9 \pm 0.03 \mathrm{y}$ & $35.2 \pm 0.06 \mathrm{~b}$ & $15.4 \pm 0.05 \mathrm{y}$ \\
\hline & 8 & 28 & $5.3 \pm 0.09 \mathrm{~d}$ & $1.7 \pm 0.05 \mathrm{y}$ & $10.8 \pm 0.09 \mathrm{c}$ & $3.9 \pm 0.08 \mathrm{y}$ \\
\hline \multirow[t]{2}{*}{ BSA } & 7 & 32 & $68.8 \pm 0.12 \mathrm{a}$ & $20.6 \pm 0.06 x$ & $56.6 \pm 0.12 \mathrm{a}$ & $40.1 \pm 0.09 \mathrm{x}$ \\
\hline & 8 & 44 & $28.5 \pm 0.09 \mathrm{c}$ & $2.9 \pm 0.05$ y & $38.6 \pm 0.09 \mathrm{~b}$ & $16.7 \pm 0.07 \mathrm{y}$ \\
\hline
\end{tabular}

Number of replicates, 3. Different letters within columns differ significantly ((a-d): $P<0.05 ;(\mathrm{x}, \mathrm{y}) P<0.01)$.

No interaction between blastocyst quality and in vitro production system was obtained for in vitro survival to vitrification (data not shown). Blastocysts judged as quality A showed improved development rates after vitrification and warming over quality B blastocysts within all groups. Therefore, we presented the cumulative effect of quality (Table 2) as corrected by treatment, replicate and age.

The presence of Vero cells during IVM did not significantly improve the survival to vitrification (data not shown). Therefore, results on embryo survival rates after vitrification/warming are presented as cumulative by treatments and embryo age at cryopreservation (Table 3). The effects included in the model were replicate and blastocyst quality.

Day 7 embryos showed higher survival rates than their Day 8 counterparts obtained in the three culture systems. Day 7 blastocysts produced in Vero cells or in $\mathrm{SOF}+\mathrm{BSA}$ survived at higher rates than those produced in SOF + FCS at 24 and $48 \mathrm{~h}$ after warming. However, Day 7 blastocysts produced in SOF + BSA hatched at 24 and $48 \mathrm{~h}$ and at higher rates than the embryos vitrified in the other groups.

Embryo culture in SOF + BSA produced Day 8 blastocysts with hatching rates lower than those of the Day 7 embryos, but similar to those obtained with Day 7 blastocysts produced in Vero cells or SOF + FCS.

Blastocysts produced in SOF + BSA showed a lighter aspect than those obtained in the remainder groups, which looked dark.

\section{Discussion}

At present, slow freezing and vitrification are commonly used to cryopreserve bovine embryos. However, slow freezing of in vitro produced embryos reduced post thaw survival rates compared with their in vivo counterparts, mostly due to their susceptibility to ice crystal formation [29]. The modification of cryopreservation methods or the improvement of embryo quality by optimising the in vitro embryo environment could both contribute to overcome this problem. In the present work we have developed a simple culture medium providing high survival and hatching rates after vitrification/warming of Day 7 bovine blastocysts. The IVM with Vero cells did not improve either embryo development or embryo ability to survive to vitrification and warming. Both, the embryo quality and the age of the embryo influenced survival and hatching rates after vitrification.

Despite the efficiency of in vitro production systems in yielding considerable numbers of embryos, the major fall-off in in vitro embryo development occurs between the two-cell and blastocyst stages, suggesting that postfertilization embryo culture is the most critical period of the process in terms of determining the blastocyst quality $[35,36]$.

Our developmental data are similar to those obtained by Menck et al. [19] with Vero cells and B2, and those reported by Holm et al. [27] for embryos developed in SOF. Although some data about culturing embryos in SOF with high BSA concentrations have been reported [37], no comparisons among SOF with FCS or high BSA concentrations, and co-culture with Vero cells have been described in terms of vitrification survival.

It has been demonstrated previously that various coculture systems based on complex media and combining different somatic cells, including oviductal cells, cumulus granulosa cells, uterine and skin cells, Vero cells and BRL cells, supported a high rate of development of bovine embryos to blastocysts (for review, see [22]). The percentage of early embryos that developed to blastocysts is similar for a variety of cells used in co-culture $[17,22,23]$. Also, it has been shown that when either B2 [38] or TCM199 [17,22,23] were 
combined with somatic cells in a co-culture system, both media supported a higher rate of development to blastocysts than did control media without cells. Hasler [39], showed that embryos cultured in a B2-BRL coculture exhibited faster development, with a higher total number of blastocysts and more cells than B2 medium without co-culture. Rizos and co-workers [13] obtained more blastocysts after in vitro culture in SOF than in TCM199 in the presence of a monolayer of granulosa cells.

Co-culture systems for mammalian embryos normally contain serum, as much for the benefit of the coculture cells as for possible benefits to the embryos. Addition of serum to the culture medium increases the speed of development manifested in a lack of normal morula compaction and an earlier appearance of the blastocyst $[8,23]$. This fact is well stated in our results which showed higher Day 6 blastocysts rates in embryos developed with FCS (Groups Vero and FCS), than in the group SOF-BSA.

In our work, the presence of BSA in culture led to a slow embryo development, leading to more Day 8 blastocysts being vitrified than in the presence of FCS. These results contrast with those obtained by Lazzari et al. [37], who showed that embryos derived from SOF-BSA $\left(16 \mathrm{~g} \mathrm{~L}^{-1}\right)$ or SOF-serum $(20 \%$ human serum) had both a similar effect, enhancing cell proliferation and accelerating development as related to the embryos cultured in sheep oviduct.

From our survival results after vitrification/warming, we can conclude that Day 7 blastocysts produced in Vero cells or in SOF + BSA survived at higher rates than those produced in SOF + FCS. Interestingly, Day 8 embryos produced in SOF + BSA survived and hatched at similar rates than their Day 7 counterparts produced in both Vero cells and SOF-FCS. Although the age of the embryo seems to influence cryosurvival $[10,40]$, our results in the group SOF + BSA suggest that not only Day 7, but Day 8 expanded blastocysts could be vitrified with satisfactory survival rates.

The ability of in vitro produced embryos to survive cryopreservation, an indicator of embryo quality $[4,5,8,12,41,42]$, is affected by culture conditions. Thus, Dinnyés et al. [29] reported high survival rates (85\% and 90\%) after vitrification/warming of Day 8 expanded embryos produced in SOF without and with FCS, respectively; the hatching rates the above authors obtained for embryos produced in SOF + FCS (63\%) are comparable to the survival rates in our work in the Vero and BSA groups.

Blastocysts produced with cells (TCM199 or SOF, both with $10 \%$ FCS) had higher survival rates than those cultured in SOF alone $[13,17]$. Moreover, these authors demonstrated that it is necessary a minimum period of 4 days in co-culture with granulosa cells for improving the embryo quality to survive vitrification and warming. In our work, the cells were present during the whole culture period ( 7 or 8 days).

Other works $[8,26,43]$ showed that bovine embryos cultured without serum had more cryo-resistance, particularly when embryos were vitrified. Mucci et al. [43] observed a lack of benefit from the serum on embryo development, probably as a consequence of differences in experimental conditions compared with other authors, such as the absence of co-culture during the whole development period, and the type and concentration of serum used. Nevertheless, the comparisons among researchers are difficult because in vitro production systems, and procedures to cryopreserve and determine survival are different between laboratories.

Culture in the absence of serum results in less lipid accumulation in embryos [26]. A further finding is that embryos with less lipids, produced without serum in the medium, also cryopreserve more successfully that lipidrich embryos produced in the presence of serum $[4,8,26]$. The relationship between the lipid droplets (LD) accumulated in the embryo and its impaired ability to survive cryopreservation has been clearly demonstrated [7,26,44]. Abe et al. [26] showed that bovine embryos cultured in serum containing media, abnormally accumulated lipids into their cytoplasm, although in vitro development was unaffected. In their work, morulae and blastocysts showed many small size LD in the absence of serum, while large lipid vesicles were described in cultures with serum. In this study, the electronic microscopy showed a great number of LD in the cytoplasm of trophectoderm (TE) and the inner cell mass (ICM) of blastocysts developed in the presence of FCS, compared to those cultured in the same medium but without serum. This work was first to demonstrate that the presence of serum, and no other media components, was the primary cause of most developmental differences observed between in vitro produced embryos.

In embryos, the maturation of mitochondria during IVC is associated with increases in metabolism reflected in the oxygen consumption [45] and $\mathrm{CO}_{2}$ production [46] and it appears to be related to depletion of stored products (cytoplasmic lipids). This fact could imply a strong relationship between the mitochondrial stage and the lipid droplets. Consequently, the cryopreservation procedures having effects on lipid droplets could alter the mitochondrial structure, 
affecting further embryo development after thawing, as proposed by Diez et al. [44].

On the other hand, the presence of large amounts of lipid droplets in embryos developed in serum-supplemented media probably damages cellular mechanisms responsible for repairing plasma membranes after cryopreservation. Moreover, the addition of serum could promote the incorporation of saturated fatty acids into the plasma membrane, since in adult ruminants these fatty acids are predominant in serum [47]. This incorporation could probably induce changes in membrane composition, making it more rigid, and unable to withstand cryopreservation [43]. In our study, embryos produced in the presence of BSA showed a lighter aspect than those developed in the presence of serum, which suggests a lower amount of lipids in the cytoplasm. Contrarily, embryos produced both with FCS and with Vero cells showed a darker aspect, pointing towards an increased lipid accumulation.

Although cell counts have not been performed in this work, it is commonly accepted that the presence of somatic cells during the IVC increases the number of the cells of the embryo [15]. It has been also reported that embryos developed in serum containing media have a higher proportion of TE cells compared with embryos produced in serum-free media [48]. TE cells are crucial for blastocoele re-expansion and maintenance after cryopreservation, and the higher lipid contents in TE than the ICM [26] could make TE cells particularly damaged during cryopreservation. In our case, the lighter appearance of blastocysts produced in SOF-BSA suggests a lower lipid contents in these blastocysts and explains the increased survival rates and hatching obtained after vitrification/warming.

The cell type used in co-culture and incubation conditions after vitrification and warming may influence blastocyst survival and quality after cryopreservation Kaidi et al. [49]. Thus, embryos survived at higher rates when cultured in BRL than granulosa cells, and 20\% O2 led to higher hatching rates than $5 \% \mathrm{O} 2$ in co-culture. Finally, these authors conclude that the use of a co-culture system for warmed embryos ensures the best system to obtain better survival rates $[13,49]$.

Our culture system of SOF with BSA allows obtaining hatching rates after vitrification/warming higher than those obtained after embryo co-culture with Vero cells in B2 and FCS. Moreover, this system permits to obtain hatching rates from Day 8 blastocysts comparable to the Day 7 hatching rates from embryos produced in Vero cells. Embryo transfer to recipients are envisaged to analyze pregnancy rates obtained from embryos produced in SOF with $20 \mathrm{~g} \mathrm{~L}^{-1}$ of BSA. To reach a complete expansion of the in vitro procedures, further studies are needed focusing on the effects of culture systems on embryo quality, in terms of survival rates to cryopreservation.

\section{Acknowledgements}

Marta Muñoz is sponsored by a grant from FICYT. To Fernando García Ruiz for recovery of slaughterhouse ovaries. Supported by AGL-2001-0379.

\section{References}

[1] Lu KH, Gordon I, Gallagher M, McGovern H. Pregnancy established in cattle by transfer of embryos derived from in vitro fertilisation of oocytes matured in vitro. Vet Rec 1987;121:259-60.

[2] Goto K, Kajihara Y, Kosaka S, Koba M, Nakanishi Y, Ogawa K. Pregnancies after co-culture of cumulus cells with bovine embryos derived from in-vitro fertilization of in-vitro matured follicular oocytes. J Reprod Fertil 1988;83:753-8.

[3] Lonergan P, Rizos D, Ward F, Boland MP. Factors influencing oocyte and embryo quality in cattle. Reprod Nutr Dev 2001;41:427-37.

[4] Lonergan P, Rizos D, Gutiérrez-Adán A, Moreira MB, Pintado $\mathrm{B}$, de la Fuente J. Temporal divergence in the pattern of messenger RNA expression in bovine embryos cultured from the zygote to blastocyst stage in vitro or in vivo. Biol Reprod 2003;69:1424-31.

[5] Rizos D, Fair T, Papadopoulos S, Boland MP, Lonergan P. Developmental, qualitative, and ultrastructural differences between ovine and bovine embryos produced in vivo or in vitro. Mol Reprod Dev 2002;62:320-7.

[6] Rizos D, Ward F, Duffy P, Boland MP, Lonergan P. Consequences of bovine oocyte maturation, fertilization or early embryo development in vitro versus in vivo: implications for blastocyst yield and blastocyst quality. Mol Reprod Dev 2002;61:234-48.

[7] Leibo SP, Loskutoff NM. Cryobiology of in-vitro-derived bovine embryos. Theriogenology 1993;39:81-94.

[8] Rizos D, Gutiérrez-Adán A, Perez-Garnelo S, De La Fuente J, Boland MP, Lonergan P. Bovine embryo culture in the presence or absence of serum: implications for blastocyst development, cryotolerance, and messenger RNA expression. Biol Reprod 2003;68:236-43.

[9] Farin PW, Farin CE. Transfer of bovine embryos produced in vivo or in vitro: survival and fetal development. Biol Reprod 1995;52:676-82.

[10] Imai K, Matoba S, Dochi O, Shimohira I. Different factors affect developmental competence and cryotolerance in in vitro produced bovine embryo. J Vet Med Sci 2002;64:887-91.

[11] Lonergan P, Rizos D, Kanka J, Nemcova L, Mbaye AM, Kingston M, et al. Temporal sensitivity of bovine embryos to culture environment after fertilization and the implications for blastocyst quality. Reproduction 2003;126:337-46.

[12] Rizos D, Lonergan P, Boland MP, Arroyo-Garcia R, Pintado B, de la Fuente J, et al. Analysis of differential messenger RNA 
expression between bovine blastocysts produced in different culture systems: implications for blastocyst quality. Biol Reprod 2002;66:589-95.

[13] Rizos D, Ward F, Boland MP, Lonergan P. Effect of culture system on the yield and quality of bovine blastocysts as assessed by survival after vitrification. Theriogenology 2001;56:1-16.

[14] Massip A, Mermillod P, Dinnyes A. Morphology and biochemistry of in-vitro produced bovine embryos: implications for their cryopreservation. Hum Reprod 1995;10:3004-11.

[15] Fukuda Y, Ichikawa M, Naito K, Toyoda Y. Birth of normal calves resulting from bovine oocytes matured, fertilized, and cultured with cumulus cells in vitro up to the blastocyst stage. Biol Reprod 1990;42:114-9.

[16] Fukui Y, Ono H. In vitro development to blastocyst of in vitro matured and fertilised bovine oocytes. Vet Rec 1988;122:282.

[17] Aoyagi Y, Fukui Y, Iwazumi Y, Urakawa M, Ono H. Effects of culture systems on development of in vitro fertilized bovine ova into blastocysts. Theriogenology 1990;34:749-59.

[18] Voelkel SA, Hu YX, Moore K, Bondioli KR. Freeze survival of bovine embryos produced by in vitro maturation, fertilization and culture of oocytes. Theriogenology 1992;37:317 (abstr).

[19] Menck MC, Guyader-Joly C, Peynot N, Le Bourhis D, Lobo RB, Renard JP, et al. Beneficial effects of Vero cells for developing IVF bovine eggs in two different co-culture systems. Reprod Nutr Dev 1997;37:141-50.

[20] Carolan C, Lonergan P, Van Langendonckt A, Mermillod P. Factors affecting bovine embryo development in synthetic oviduct fluid following oocyte maturation and fertilization in vitro. Theriogenology 1995;43:1115-28.

[21] Thompson JG, Mitchell M, Kind KL. Embryo culture and longterm consequences. Reprod Fertil Dev 2007;19:43-52.

[22] Gordon I. Laboratory production of cattle embryos.. Wallingford: CAB International; 1994

[23] Van Langendonckt A, Donnay I, Schuurbiers N, Auquier P, Carolan C, Massip A, et al. Effects of supplementation with fetal calf serum on development of bovine embryos in synthetic oviduct fluid medium. J Reprod Fertil 1997;109:87-93.

[24] Lonergan P, O'Kearney-Flynn M, Boland MP. Effect of protein supplementation and presence of an antioxidant on the development of bovine zygotes in synthetic oviduct fluid medium under high or low oxygen tension. Theriogenology 1999;51: 1565-76.

[25] Pinyopummintr T, Bavister BD. Development of bovine embryos in a cell-free culture medium: effects of type of serum, timing of its inclusion and heat inactivation. Theriogenology 1994;41:1241-9.

[26] Abe H, Yamashita S, Satoh T, Hoshi H. Accumulation of cytoplasmic lipid droplets in bovine embryos and cryotolerance of embryos developed in different culture systems using serumfree or serum-containing media. Mol Reprod Dev 2002;61:5766.

[27] Holm P, Booth PJ, Schmidt MH, Greve T, Callesen H. High bovine blastocyst development in a static in vitro production system using SOFaa medium supplemented with sodium citrate and myo-inositol with or without serum-proteins. Theriogenology 1999;52:683-700.

[28] Wrenzycki C, Herrmann D, Lucas-Hahn A, Lemme E, Korsawe $\mathrm{K}$, Niemann $\mathrm{H}$. Gene expression patterns in in vitro-produced and somatic nuclear transfer-derived preimplantation bovine embryos: relationship to the large offspring syndrome? Anim Reprod Sci 2004;82-83:593-603.
[29] Dinnyés A, Carolan C, Lonergan P, Massip A, Mermillod. Survival of frozen or vitrified bovine blastocysts produced in vitro in synthetic oviduct fluid. Theriogenology 1996;42:142539.

[30] Vajta G, Holm P, Kuwayama M, Booth PJ, Jacobsen H, Greve T, et al. Open Pulled Straw (OPS) vitrification: a new way to reduce cryoinjuries of bovine ova and embryos. Mol Reprod Dev 1998;51:53-8.

[31] Vajta G, Rindom N, Peura TT, Holm P, Greve T, Callesen H. The effect of media, serum and temperature on in vitro survival of bovine blastocysts after Open Pulled Straw (OPS) vitrification. Theriogenology 1999;52:939-48.

[32] Hidalgo CO, Fernández I, Duque P, Facal N, Díaz E, Prendes JM, et al. Primeros terneros producidos in vitro tras punción ecoguiada de folículos ováricos. Archivos de Zootecnia 2002;51:411-22.

[33] Parrish JJ, Susko-Parrish JL, Leibfried-Rutledge ML, Critser ES, Eyestone WH, First NL. Bovine in vitro fertilization with frozenthawed semen. Theriogenology 1986;25:591-600.

[34] SAS Version 8. 2. Cary Inc.: SAS Institute Inc.; 1999.

[35] Fernández-González R, Moreira P, Bilbao A, Jiménez A, PérezCrespo M, Ramírez MA, et al. Long-term effect of in vitro culture of mouse embryos with serum on mRNA expression of imprinting genes, development, and behavior. Proc Nat Acad Sci USA $2004 ; 101: 5880-5$.

[36] Lonergan P. State-of-the-art embryo technologies in cattle. Soc Reprod Fertil (Suppl) 2007;64:315-25.

[37] Lazzari G, Wrenzycki C, Herrmann D, Duchi R, Kruip T, Niemann $\mathrm{H}$, et al. Cellular and molecular deviations in bovine in vitro-produced embryos are related to the large offspring syndrome. Biol Reprod 2002;67:767-75.

[38] Thibodeaux JK, Myers MW, Goodeaux LL, Menezo Y, Roussel JD, Broussard JR, et al. Evaluating an in vitro culture system of bovine uterine and oviduct epithelial cells for subsequent embryo co-culture. Reprod Fertil Dev 1992;4:573-83.

[39] Hasler JF. In vitro culture of bovine embryos in Menezo's B2 medium with or without co-culture and serum: the normalcy of pregnancies and calves resulting from transferred embryos. Anim Reprod Sci 2000;60-61:81-91.

[40] Saha S, Rajamahendran R, Boediono A, Sumantri C, Suzuki T. Viability of bovine blastocysts obtained after 7, 8 or 9 days of culture in vitro following vitrification and one-step rehydration. Theriogenology 1996;46:331-43.

[41] Lonergan P, Rizos D, Gutiérrez-Adán A, Fair T, Boland MP. Oocyte and embryo quality: effect of origin, culture conditions and gene expression patterns. Reprod Dom Anim 2003;38:25967.

[42] Costa Pereira D, Alves Nunes M, Rumpf D, Rumpf R. Evaluation of different culture systems on the in vitro production of bovine embryos. Theriogenology 2005;63:1131-41.

[43] Mucci N, Aller J, Kaiser GG, Hozbor F, Cabodevila J, Alberio RH. Effect of estrous cow serum during bovine embryo culture on blastocyst development and cryotolerance after slow freezing or vitrification. Theriogenology 2006;65:1551-62.

[44] Diez C, Heyman Y, Le Bourhis D, Guyader-Joly C, Degrouard J, Renard JP. Delipidating in vitro-produced bovine zygotes: effect on further development and consequences for freezability. Theriogenology 2001;55:923-36.

[45] Mills RM, Brinster RL. Oxygen consumption of preimplantation mouse embryos. Exp Cell Res 1967;47:337-44.

[46] Brinster RL. Carbon dioxide production from glucose by the preimplantation mouse embryos. Exp Cell Res 1967;47:271-7. 
[47] Pethick DW, Dunshea RR. Fat metabolism and turnover. In: Forbes JM, France, editors. Quantitative aspects of ruminant digestion and metabolism. J. Cab International; 1993. p. 515.

[48] Crosier AE, Farin PW, Dykstra MJ, Alexander JE, Farin CE. Ultrastructural morphometry of bovine blastocysts produced in vivo or in vitro. Biol Reprod 2001;64:1375-85.
[49] Kaidi S, Donnay I, Van Langendonckt A, Dessy F, Massip A. Comparison of two co-culture systems to assess the survival of in vitro produced bovine blastocysts after vitrification. Anim Reprod Sci 1998;52:39-50. 